Saint Louis University School of Law

Scholarship Commons

All Faculty Scholarship

2009

\title{
Governing in the Vernacular: Eugen Ehrlich and Late Habsburg Ethnography
}

Monica E. Eppinger

Saint Louis University School of Law

Follow this and additional works at: https://scholarship.law.slu.edu/faculty

Part of the Law Commons

\section{Recommended Citation}

Monica Eppinger, Governing in the Vernacular: Eugen Ehrlich and Late Habsburg Ethnography, in Living Law: Reconsidering Eugen Ehrlich, Edited By Marc Hertogh. Oxford: Hart, 2009.

This Article is brought to you for free and open access by Scholarship Commons. It has been accepted for inclusion in All Faculty Scholarship by an authorized administrator of Scholarship Commons. For more information, please contact erika.cohn@slu.edu, ingah.daviscrawford@slu.edu. 


\section{Living Law}

Reconsidering Eugen Ehrlich

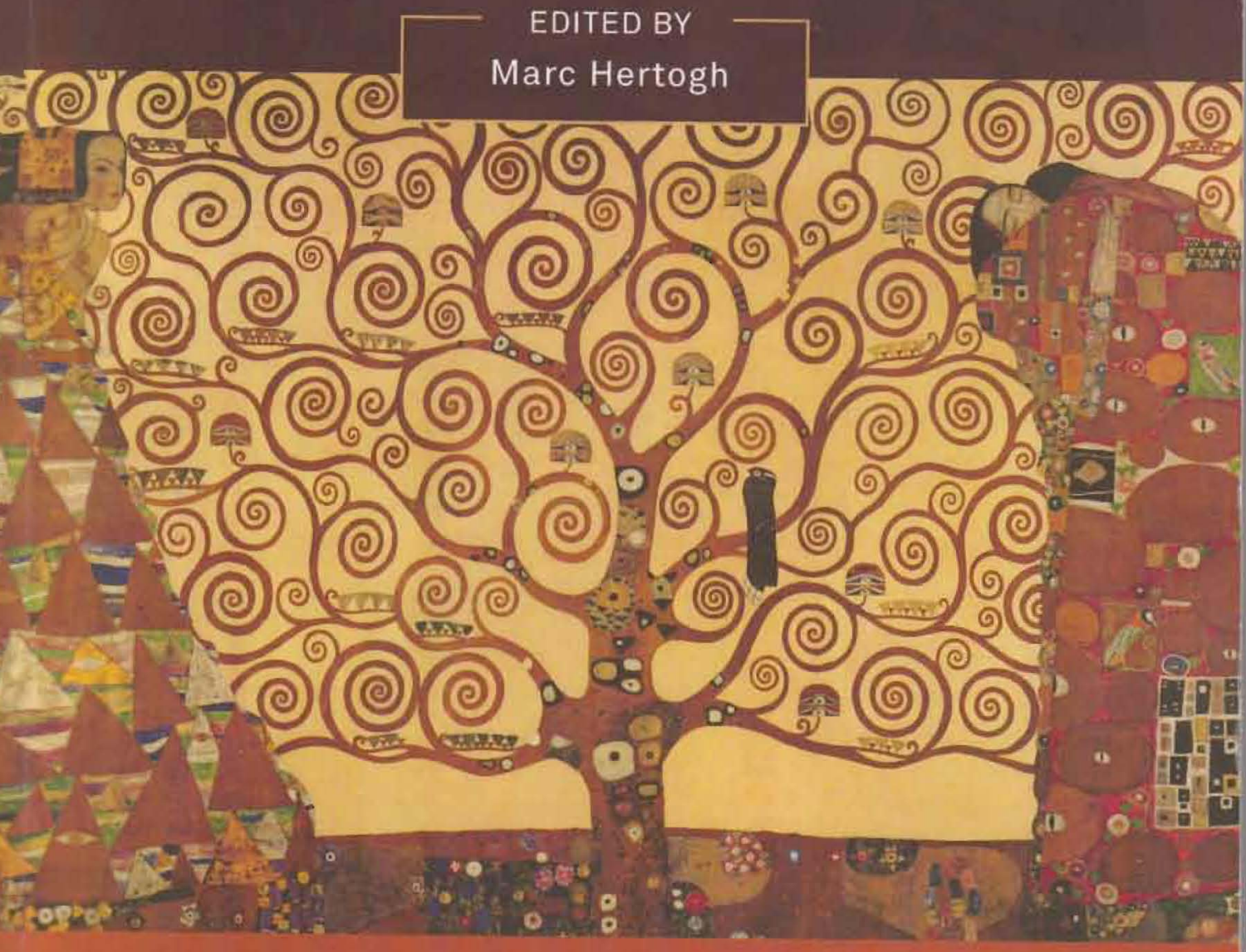




\title{
Living Law Reconsidering Eugen Ehrlich
}

\author{
Edited by \\ Marc Hertogh \\ Oñati International Series in Law and Society \\ A SERIES PUBLISHED FOR THE OÑATI INSTITUTE \\ FOR THE SOCIOLOGY OF LAW
}

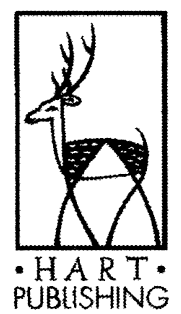

OXFORD AND PORTLAND OREGON

2009 


\title{
2 \\ Governing in the Vernacular: Eugen Ehrlich and Late Habsburg Ethnography
}

\author{
MONICA EPPINGER
}

\section{INTRODUCTION}

$\mathrm{E}$ UGEN EHRLICH'S LEGACY in Anglophone scholarship presents us with a conundrum. Legal scholars recognise Ehrlich's work as having decisive effects on the course or twentietn-century American jurisprudence. US legal historians cite his contributions to the Free School ${ }^{1}$ that exerted a dispositive influence on the inception of Legal Realism and the creation of whole new bodies of US law; critical legal studies scholars ${ }^{2}$ and legal anthropologists ${ }^{3}$ still credit his understanding of 'living law' in their work on the limits of formal law. While Ehrlich's ideas are acknowledged for their influences, his claims themselves are rarely probed and the man himself is largely unknown. We are left with little to evaluate the competing interpretations of his legacy. Which version-visionary foundationlayer for enlightened administration or righteous critic of state fetishismis more true to Ehrlich's project? Anglophone scholarship offers few answers. Beyond habitual genuflection by the meticulous legal academic and brief, rare citation by the specialised historian, ${ }^{4}$ Ehrlich is a cipher. Little is available in English-language sources about his life or intellectual

1 See, eg J Whitman, book review of François Gény e la scienza giurdica del Novecento (March 1995) 67 The Journal of Modern History 176.

2 See, eg D Kennedy, 'Two Globalizations of Law and Legal Thought: 1850-1968' 36 Suffolk University Law Review 631 at 648-9.

3 See, eg L Nader, The Lafe of the Law (Berkeley, University of California Press, 2002) 136 (hereinafter: Nader, Life). See also L Nader, 'The Anthropological Study of Law' (December 1965) in The Ethnography of Law (special issue of American Anthropologist, L Nader (ed), 67 American Anthropologist 6).

4 See, eg B Hett, "The "Captain of Koepenick" and the Transformation of German Criminal Justice, 1819-1914' (2003) 36 Central European Jurisprudence 1. 
formation. ${ }^{5} \mathrm{He}$ is virtually unmentioned in the history of Bukovina or Ukraine, although he is undoubtedly the most internationally influential legal scholar either has produced. This is particularly surprising, given how seriously legal scholars took Ehrlich's advice to examine the social movement behind a legal thinker in order to understand what is going on and possible causes. ${ }^{6} \mathrm{~A}$ background contention of this chapter is that this gap in our understanding of Ehrlich's life leaves us vulnerable to misreading or missing some points in his work.

How much do we know of Ehrlich's setting and personal history? The bare facts do not reveal much. Ehrlich was born in Chernivtsi, the capital of Bukovina in Austria (now Ukraine). He trained at the University of Vienna in law and served as a docent there until returning to Chernivtsi as professor of Roman law in 1898. He was made rector of the university in 1906 and died in 1922.

Ehrlich's program gives us a point of entry to examine his principal ideas more closely. In a talk to the Juridical Society of Vienna in 1903, Ehrlich lays out a new vision for what law is and how legal science should proceed. Ehrlich contrasts a 'dynamic conception of law'-which legal science until then was ill-equipped to fathom-with the 'traditional, dogmatic conception' of a bounded set of legal rules governed by formal logic and sophisticated doctrine. ${ }^{7}$ To understand law in its dynamic conception, Ehrlich suggests that we turn to three sources: decisions of the courts (mindful that every decision is the result of a number of factors, only one of which is the text of a legal rule); actual legal transactions that have not had to resort to courts or government agencies for adjudication; and, most importantly, the 'facts of daily life, apart from their legal aspect'. 'In reality life creates primarily its own rules', apart from the rules of law. ${ }^{8}$ Legal scholars should undertake investigations of real life and furnish them back to the courts to inform judicial decisions. ${ }^{9}$ In this program, Ehrlich sets up a new challenge for legal science that demands new equipment. ${ }^{10}$

\footnotetext{
5 Notable exceptions are A Likhovski, 'Czernowitz, Lincoln, Jerusalem, and the Comparative History of American Jurisprudence' (2003) 4 Theoretical Inquiries in Law 621; and B Weiler, 'E Pluribus Unum? The Kakanian Intellectual and the Question of Cultural Pluralism', MS of paper presented at the conference, "The Contours of Legitimacy in Central Europe: New Approaches in Graduate Studies", at St Anthony's College Oxford, available at <http://users. ox.ac.uk/ oaces/conference/papers/Bernd_Weiler.pdf> accessed 22 July 2008.

${ }^{6}$ E Ehrlich, 'Judicial Freedom of Decision: Its Principles and Objects' (a translation of Ehrlich's 'Freie Rechtsfindung und freie Rechtswissenschaft' (Leipzig, 1903)) in E Bruncken and L Register (trs), The Science of Legal Method: Selected Essays by Various Authors (New York, Macmillan, 1921) 78 (hereinafter: Ehrlich, 'Judicial Freedom').

7 Ibid 78 .

8 Ibid 78-80.

9 Ibid 83.

10 This term comes from Paul Rabınow. See P Rabinow, Anthropos Today: Reflections on Modern Equipment (Princeton, NJ, Princeton Unıversity Press, 2003).
} 
When he searched for adequate equipment, Ehrlich found a technology increasingly common in his milieu, the Slavic hinterlands of the Habsburg empire around the turn of the twentieth century. ${ }^{11}$ The tool was ethnography. ${ }^{12}$ Ehrlich did not invent this method of inquiry-it was already practised throughout central Europe-but he did use it in new ways. In this chapter, I examine the practice of ethnography as an artifact. In trying to learn more about Ehrlich's intellectual formation, ethnography focuses our attention on where he came from, as a tool specific to Ehrlich's time and location, and on where he ends up, as a tool that transformed him and his discipline. I propose that ethnography was one answer to a certain set of problems formulated in the late Habsburg period. This chapter, then, explores Ehrlich's work, specifically his methodological program using ethnography for making legal decisions. I will take up, in turn, what ethnography meant in his time; a survey of the late Habsburg landscape in which ethnography was conceived as a means for solving practical problems; and finally some modest proposals for further work.

\section{THE DESCRIPTIVE VERSUS NORMATIVE REGISTER IN FIN-DE-SIÈCLE ETHNOGRAPHY}

Ethnography is a familiar term to us, but we should not assume too much; its meaning has undergone considerable slippage since Ehrlich's time. It is worth examining, briefly, how ethnography was understood in AustriaHungary at the turn of the century.

Ethnography was meant first as a descriptive genre. Critical thinkers dating back to Kant have marked a categorical difference between a descriptive work and a normative work. Ehrlich articulated his view of this demarcation in the critique of Montesquieu's L'Esprit des Lois that he wrote for Justice Holmes. The French term devoir permits an elision between the meaning of 'ought' and 'is', he says, signifying 'both what ought to be and what must be'. Montesquieu mostly uses devoir in the former meaning, but he was influenced enough by natural law beliefs 'as not to draw a sharp line between the law that ought to be and the law that is',

11 This should not be read as the start of an argument for environmental or social determinism nor, necessarily, a claim for uniqueness. It is rather an effort to explore the particulars of Ehrlich's context.

${ }^{12}$ Ethnographers from Bukovina and Galicia working at the same time as Ehrlich did as a publishing jurist include the team working out of L'viv (or, in Austrian or Yiddish, Lemberg), of Xv Volkov, M Zubritskiy, M Russov, M Litvinova-Bartush, A Veretelnyk, M Shishkevych, V Domanitzkiy, Ol Radakov, M Dikarev; famed folklorist V Hnatiuk; folklorist and writer Sh Aleykum; ethnographer of legal affairs S Dniestrzanski; and, overlapping with the last decade of Ehrlich's career, B Malinowski. 
which Ehrlich denounces as vagueness. ${ }^{13}$ Ehrlich intended his ethnography to be a record of what people are actually doing, rather than a prescription for what they should be doing.

He points us to several peers, most of them Austro-Hungarian, who in his view have taken up the same agenda as he has. Bogošič, a Croat, drew up a questionnaire (of more than 800 questions!), the answers to which form the basis of a work on southern Slavs (Zbornik Sadašnih Pravnih Običaja Južnih Slovena). Bobčev adopted Bogošič's method and produced a collection of Bulgarian customary law, Sbornik na Blgarski Juriditski Obitschai. ${ }^{14}$ They ventured into the countryside like nineteenth-century Romantic folklorists, collecting legal custom instead of fairytales. The survey method was also taken up by fin-de-siècle British anthropology: witness members of the 1896 Torres Straights expedition clambering ashore to query a small number of informants from a given list of questions. ${ }^{15}$ This hit-and-run methodology could yield staggering amounts of data in a short period of time. We will examine later how Ehrlich distinguishes his work from theirs and how his work transforms the method. This initial look at least gives us a glimpse of the starting point of ethnography when Ehrlich took it up. The ethnographer was collector and describer; his work involved collecting data through surveys, usually in rural areas, and writing it up into detailed descriptions.

\section{BEYOND IS VERSUS OUGHT}

That said, we should be aware that Ehrlich and his central European peers regarded ethnography as potentially more active than we would be prone to. Even if a description was not delivered in a normative register, Ehrlich and his contemporaries understood that description under some circumstances could be creative-a form of performative speech. ${ }^{16}$ Here is how. In late Habsburg Austria, ethnography was used as a synonym, in some instances, for ethnicity or ethnic group. ${ }^{17}$ Within an empire where certain rights were, by definition, group rights (meaning that recognition of some rights depended on a certain kind of legal recognition of the group), discerning,

13 E Ehrlich, 'Montesquieu and Sociological Jurisprudence' (April 1916) 29 Harvard Law Review 582 at 583 (hereinafter: Ehrlich, 'Montesquieu').

${ }^{14}$ E Ehrlich, Fundamental Principles of the Sociology of Law, W Moll (tr) (New York, Russell and Russell, 1962 (1913)) 464-5 (hereinafter: Ehrlich, Fundamental Principles). The other peer Ehrlich cites is a Spaniard, Costa, who used direct observation to produce a compendium of legal relations in real life.

15 For one ethnography resulting from such an expedition, see W Rivers, The Todas (New York, Macmillan, 1906).

16 For an explanation of performative speech, see JL Austin, How to Do Things with Words (Cambridge, MA, Harvard University Press, 1962).

$1^{\urcorner}$T Snyder, personal communication, 17 April 2006. 
naming, describing a social group in a certain way could be part of building an argument for group recognition. ${ }^{18}$ Description could be a political act or have political consequences. 'Ethnicity' and 'nation' were both terms for politically aspirant groups. Turn-of-the-century Ukrainian nationalist Ivan Franko called for an independent country within what he and his generation called 'ethnographic' borders. ${ }^{19}$ The Ivan Frankos, the Theodor Herzls, of Austria-Hungary understood that ethnography, creating a written record of an ethnos, could serve to etch ethnos in consciousness, map it onto territory, inscribe it in history. This logic was later borne out in the entry into international law of the right of a people to self-determination and the emergence of Habsburg successor states based on claims of ethnicity and nationality-a Bulgaria, a Poland, eventually an Israel, a Ukraine. Habsburg political organisation set the stage for nation-state successors by according legal recognition of certain rights based on inclusion in or exclusion from a group that had established some precursor claims. Over time, ethnography was a way to stake a claim as a 'people', to build an argument for self-determination. That came after the war (World War I), of course: a central Europe of nation-states was beyond Ehrlich's historical horizon and, as far as we can discern, was nowhere in the realm of his expectations. To understand some of the impetus for ethnography before the war, we need to look at the Austria-Hungary that preceded. We start with a most local institution, the university in Ehrlich's hometown where he taught and did most of his research into living law, and then we move on to his native province and the empire into which it fit.

\section{THE ETHNOGRAPHER}

\section{Ehrlich's Bukovina and Vienna's Ehrlich}

\section{Bukovina}

The University of Czernowitz, where Ehrlich would become professor in the law school and then rector, came into being as part of a wave of Liberal state institution-building in the $1870 \mathrm{~s} .{ }^{20} \mathrm{~A}$ member of Bukovina crown

18 This kind of power of description is not unknown in the US legal system. Jeremy King, for example, compares Habsburg group classifications and their effects with a similar process in contemporary US affirmative action law. See, eg J King, 'Group Rights in Liberal Austria: the Dilemma of Classificatory Procedure' (November 2005) (MS).

19 T Snyder, The Reconstruction of Nations: Poland, Ukraine, Lithuania, Belarus 1569 1999 (New Haven, CT, Yale University Press, 2003).

20 After they won a parliamentary majority, Liberals displaced the army from its parade grounds in the centre of Vienna and on the site erected buildings of the University of Vienna (built 1873-84) that Ehrlich attended, as well as the house of the Austrian Parliament (built 1874-83). 
land parliament, Constantin Tomaszczuk, led the campaign to convince Vienna to fund a university in Czernowitz. He argued that the monarchy would be well served by a university in its eastern borderlands as an instrument of unity through enlightenment, prestige associated with Germanlanguage science and learning, and common enculturation. A university in Czernowitz, Tomaszczuk argued, 'could be an intellectual fortress, which will secure the unity and integrity of the monarchy much better than bastions lined with cannons'. ${ }^{21}$ Two Austro-Hungarian universities, Tomaszczuk's alma mater the University of Lemberg (L'viv) and the University of Cracow, had recently (in 1870-71) been 'polonised'. Slavicism seemed provincial and separatist; the empire needed non-Slavic alternatives in the East. With the help of Baron Gheorghe Hurmuzaki, who led his fellow Romanian aristocrats in Bukovina's Landtag to support the plan, ${ }^{22}$ Tomaszczuk's initiative succeeded. The Austrian Government converted an existing theological institute into the Franz Josef University of Czernowitz, consisting of three sections (fakultäten): theology; philosophy, philology and natural sciences; and law and political economy. It opened on 4 October 1875.

The Imperial Charter for the University explicitly recognised the pluralistic population the university would serve, as well as the transcendent ideals of learning and Austrian citizenship it hoped to inculcate. It read:

As the German, so the Romanian and the Slav gladly quenches his thirst and draws strength from the fountain of German science; this in greater measure will offer him the means to retain and nurture his individuality; but it will also be an inducement to work and strive together toward the happiness and glory of our beloved fatherland, Austria. ${ }^{23}$

Reading these words today, we must remind ourselves that 'Germany' was a nascent project, having just formed as a unified country in 1871. 'German science' might here refer to affiliation with a certain Western Enlightenment discourse, expressed in German tongue, or common cause with a learned elite of Vienna and other Habsburg cities. It did not refer to a science produced on the territory of a long-standing German political entity. Hegemony was conveyed in the 'science' at least as much as in the 'German'.

21 Constantin Tomaszczuk, quoted in $\mathrm{R}$ Wagner, Vom Moldauwappen zum Doppeladler: Ausgewählte Beiträge zur Geschichgte der Bukowina (Augsburg, Hormann-Verlag, 1991) 282, cited by I Livezeanu, Cultural Politics in Greater Romania (Ithaca, Cornell University Press, 1995) 228. The author cited, Rudolf Wagner, was a student at the University of Czernowitz from 1930 to 1932. Livezeanu, tbid 228.

22 I Livezeanu, Cultural Politics in Greater Romania (Ithaca, Cornell University Press, 1995), citing Wagner.

23 M Popescu-Spineni, Instıtuțı de inaltă cultură (Vălenii-de-Munte, Datına românească, 1932) 175-76, 178, cited in Livezeanu, above n 22, 228. 
Tomaszczuk, named first rector of the new university, indicated this dual supranational orientation towards political and moral affiliation in his inaugural speech. A Liberal presumption of equality of men underwrites his assertion of the capacity of education for 'levelling up'. 'German science has a claim to universality', he said. 'And because German education has a universal importance, non-German sons of Bukovina also strive for this German university.' As if to confirm that 'German science' referred to a form of learned discourse or to the elite that produced it instead of a product of 'Germany', Tomaszczuk went on to embrace plurality and advocate openness. 'Beware to the nation which has to be afraid of the influence of foreign cultures. This nation is signing its own death certificate.' His reaffirmation,

We are not only Poles, Germans, Romanians, we are in the first place human beings, with roots in the same soil out of which we draw our common strength, and by this I mean our Austria ...

contains elements of a transcendent call to humanism, an appeal to empire loyalty and a naming of even narrower ethnic identities. Clearly, collective identity and personal loyalties were objects of interest or anxiety; his attention marks them as emergent and contested. After we look at the social world of Bukovina and the political currents that defined the Austria that encompassed it, we may return to consider whether we agree with his conclusion that ' $[t]$ he university in Czernowitz is an authentic Austrian concept'. ${ }^{24}$

Even before the university was founded, the Chernivtsi ${ }^{25}$ of Ehrlich's childhood was ruled by a Catholic dynasty, host to an eastern Orthodox seminary and home to a significant Jewish community. As provincial capital, it was the centre of its own regional hinterland (where Ehrlich chose to conduct his first ethnographic research). Vis-a-vis the wider world, the city lay on the frontier of three highly developed oecumenes (Russian, Austrian and Romanian), ruled by three different dynastic traditions and divided between mutually unintelligible language families (Slavic, Germanic and Romance). ${ }^{26}$ Traders, translators and other specialists in border hustling were native species. ${ }^{27}$ Moreover, Chernivtsi was a post on centuries-old

24 Tomaszczuk, quoted in Wagner, above n 21, 282, cited by Livezeanu, above n 22, 229.

25 A note of explanation on place names is due here. Part of the Austrian heritage is a toleration of a plethora of toponyms for a single place in the many dialects of a region. To name Ehrlich's hometown, Czernowitz is the Germanisation of the Ukrainian Chernivtsi and the Romanian Cernăuti. Because Ukrainian speakers were a plurality of the province's populatıon at the time, I will refer to it by the Ukrainian name, Chernvitsi, unless naming a specific Austrian institution like the university, in whıch case I will use Czernowitz.

26 Of course, before Austrian rule, this area had at times been part of the borderlands contested with Turkey. Assaf Likhovski has concentrated on the formative influence of location and frontier on Ehrlich's work (Likhosvskı, above n 5).

27 For an insıghtful description of a present-day Bukovına border city dynamıc, see D Blank, 'Faırvtale Cynicism in the Kingdom of Plastıc Bags: Powerlessness of Place in a Ukrainıan Border Town' (autumn 2004) 5(3) Ethnography. 
riparian trade routes connecting north-eastern Europe to the Black Sea, and from there to the Caucasus, Ottoman lands and beyond, bringing even more remote and exotic peoples and professions into contact and residence. As a result, Bukovina was a miniature of the cohabitating "compact populations' of the pluralistic empire. In this, Ehrlich enjoyed a typically Austrian childhood milieu. It is difficult to assess how quiet or remote its residents perceived Bukovina to be, but at least it was cosmopolitan. Ehrlich himself noted the diversity of community traditions thriving in this small province, counting Armenians, Germans, Jews, Russians, Ukrainians, Slovaks, Hungarians and Gypsies among those bringing different ways of life to Bukovina society. 28

This was no different for Austria as a whole. By the 1910 census, Germans constituted less than 25 per cent of the monarchy's population; the rest belonged to 'minority populations'. ${ }^{29}$ Notably, Austria and Bukovina did not cultivate an ideology of a 'melting pot'. As the Polish-Austrian subject and anthropology graduate student Bronislaw Malinowski wrote to his British dissertation adviser: 'There is no such blooming thing as an "Austrian"-it is a pure fiction'. Happily, thought Malinowski, Austria was 'a confederation of fairly autonomous peoples'.$^{30}$ This is not to overly romanticise the situation. Assimilation became an aspiration for some, and by the turn of the twentieth century, Vienna had the highest conversion rate of Jews to Christianity in Europe. ${ }^{31}$ One can, however, note the effects of an imperial policy of toleration. Communities within one locale maintained distinct practices, even languages, from each other, and the period during which Ehrlich published all of his significant writings was one of rising ethnic identification and political nationalism within the empire. Self-consciousness about group identity and curiosity about other groups were remarkable. Take, for example, the content of a series of

${ }^{28}$ E Ehrlich, 'Das lebende Recht der Völker der Bukovina' in E Ehrlich and M Rehbinder (eds), Recht und Leben: Gesammelt Schriften zur Rechtstatsachenforschung und zur Frierechtslehre (Berlin, Duncker and Humblot, 1967 (1913)) 43.

29 R Kann, The Multinational Empire: Nationalism and National Reform in the Habsburg Monarchy 1848-1914, Vol. II Empire Reform (New York, Columbia University Press, 1950) 299-307. Note that in the 1910 census, individuals were not asked their nationality but which language they spoke and which confession they belonged to. Also problematic, not all languages that were spoken in the realm could be selected as a mother tongue, only those that were recognised as 'national languages' in the terms of art XIX of the 1867 Constitution. This ruled out Yiddish; most Yiddish-speaking Jews from Galicia chose Polish and most from Bukovina chose German. This clarification adapted from Weiler, above n 5.

30 Malinowski's letter to Seligman (1914) quoted in R Firth, 'Malinowski as Scientist and as Man' in R Firth (ed), Man and Culture: An Evaluation of the Work of Bronislaw Malinowsk (London, Routledge \& Kegan Paul, 1957) 13.

31 D Edmonds and J Eidinow, Wittgenstern's Poker (New York, HarperCollins Publishers, 2001) 94 . 
for-pay adult-education courses offered by the Chernivtsi Historical Society in 1912. The syllabus included:

... world history; Ukrainian history; history of the formation of state, region, and community; ... geography of the world and Ukraine; anthropology and ethnography (about types and life ways of people); history of culture (and discovery); ... history of religion; Ukrainian language and literature; ... cooperation. ${ }^{32}$

Themes of national consciousness, curiosity about others and concerns about how to live together in a cosmopolitan mix were clearly not exclusive to Ehrlich and the law school.

Over the last decades of the nineteenth century, as the growth of capitalism and pursuit of Liberal political reforms reshaped the Austrian landscape, ethnicities and confessions responded differently to changing opportunity structures. The experience of Jews, often the limit case for European Liberal reforms seeking to replace status-based economics and politics with a free competition of equal individuals, may be looked at to measure Chernivtsi's climate for national minorities. Despite marked anti-Semitism in Vienna by the $1890 \mathrm{~s},{ }^{33}$ Chernivtsi remained relatively hospitable to Jews. In the last decades before the First World War, Chernivtsi had several Jewish mayors ${ }^{34}$ and-in part because of the law school led by Ehrlich-by 1914, 86 per cent of the town's lawyers were Jewish. ${ }^{35}$

Now that we have delineated and taken measure of Bukovina's pluralism, we must take a further step to slip into a Bukovinian mindset: we must play with the categories, for the categories themselves produced fluidity, arbitrage and slippage. Identities were assumed, lost, cultivated; groups were imagined, resented, taken pride in, historicised, credited and discredited. Witness Ehrlich's own story: born a Chernivtsi Jew, a native speaker of Polish, he became a convert to Catholicism, educated and educating in German. What do we call such a person? Certainly without error we can call him a Bukovinian and an Austrian. (Of course, the meanings of those terms too were emergent, changing over the course of Ehrlich's life.) What does this mean for his work?

I propose that this milieu fundamentally informed Ehrlich's conception of society (and, we shall see later, of law). 'Pluralist' was not an adjective that

32 'Из Наших Товарств [From our Societies]' in 3 Нова Буковина [Nova Bukovina] (Chernivtsi, 18 January 1912) 3.

33 JW Boyer, Political Radicalism in Late Imperial Vienna: Origins of the Christian Social Movement, 1848-1897 (Chicago, Chicago University Press, 1981); and C Schorske, Fin-deSiecle Vienna: Politics and Culture (New York, Knopf, 1979).

34 W McCagg, A History of Habsburg Jews, 1670-1918 (Bloomington, IN, Indiana University Press, 1989) 172-3, cited in Livezeanu, above n 22, 55.

${ }^{35}$ H Sternberg, 'Zur Geschichte der Juden in Czernowitz' in H Gould (ed), Geschichte der Juden in der Bukovina, vol 2 (Tel Aviv, Olamenu, 1962) 46, cited in Livezeanu, above n 22, 55. 
might or might not modify 'society'. Instead, pluralism for Ehrlich was an inherent quality of society:

Society is the sum total of the human associations that have mutual relations with one another. And these associations that constitute human society are very heterogeneous. ${ }^{36}$

A person belongs to many associations simultaneously; membership overlaps and changes. Moreover, the 'interdependence of all elements of social life is assumed'. ${ }^{37}$ Unlike, say, holism of British social anthropology of the time, Ehrlich's holism does not necessarily rely on a metaphor of a 'social structure', an internally consistent mechanism that could be described synchronically. For Ehrlich:

$\ldots$ the social order is not fixed and unchangeable ... It is in constant flux. Old institutions disappear, new ones come into existence, and those which remain change their content constantly. ${ }^{38}$

A living organism, not a fixed structure, is the image that comes to mind. To understand society, the sociologist must pay attention to the particularities of these many human associations. Bukovina's pluralism suggested, then, not only a particular conception of society, but a particular method of apprehending and studying it. Ethnography, for the Bukovinian Ehrlich, becomes not just a means of recording a series of folkways, but a method for understanding a sum total constantly in flux.

\section{Vienna: Liberal Order in the Era of Ausgleich}

The last decades of the Habsburg empire in which Ehrlich lived and worked were a period of compressed political change. A rise and decline of Liberalism, which in other parts of Europe took decades to articulate into political philosophy and political organisation, were squeezed into a span of roughly a quarter of a century in late Habsburg Austria. At the same time, a grand compromise (Ausgleich) with Hungary and 'little compromises' 39 with other constituent parts of Austria organised Austria-Hungary into an agglomeration of polities, each with their own

36 Ehrlich, Fundamental Principles, above n 14, 26.

37 Ehrlich, 'Montesquieu', above n 13, 586.

38 E Ehrlich, 'The Sociology of Law' (December 1922) 36 Harvard Law Review 130 at 139. We find a bridge between the two in SF Nadel. Nadel, like Malinowski, was an Austrian by birth and upbringing who became a central figure in British social anthropology, but he stayed in Vienna longer into his adulthood and his thinking was more in Ehrlich's line: more attuned to complex relations, the artificiality of boundaries and change over time. See, eg SF Nadel, Black Byzantium: the Kingdom of Nupe in Nigeria (London, Oxford University Press Publisher for the International Institute of African Languages and Cultures, 1942).

39 Jeremy King alerted me to this late Habsburg phenomenon. See, eg King, above $n$ 18. See also J King, 'Group Rıghts in Liberal Austria: Dilemmas of Equalıty' (April 2006) (MS). 
system of traditional rights. ${ }^{40}$ Where Ausgleich politics sought to preserve local traditions of noble privilege within the order of the empire, Liberalism worked from an assumption of a shared human nature justifying claims for equal political rights and an equal capacity for economic success given equal opportunity. The core tenets of Austrian Liberalism were that 'the freedom and worth of the human being are the highest values'. ${ }^{41} \mathrm{~A}$ cornerstone of the Liberal ideology was an Enlightenment belief that each person was a blank slate, theoretically equally capable, who could be raised to a common level through education. This version of laissez-faire had a progressive cast, seeking to replace privilege or charity as the basis of access to economic opportunity. In the last half-century before the First World War, Austria-Hungary's political reorganisations addressed the recurrent question: local noble privilege or universal equal rights? Throughout Ehrlich's life, accommodations to these two movements and tensions between them produced a different kind of state and innovative technologies of governance unlike anything in Europe. A few examples from its political history and technologies of governance may suffice to convey a sense of this peculiar empire.

Between 1860 and 1867, a series of pressures led to a remaking of the Austrian political order, with several fundamental changes incorporating local representation under a constitutional monarchy. The Constitutional Law (Diploma) of 1860 reinstated the old constitutions belonging to the different lands of the monarchy and gave legislative power to the provincial Diets. The Diploma was a concession of 'state-right' (a body of privileges which maintained a nation's independence while acceding to Habsburg rule) to the conservative aristocracy of different crown lands attached to their 'local liberties' and hostile to 'German centralism'. ${ }^{42}$ The Patent of 1861 established a parliament, the Reichsrat, at Vienna, with members nominated by the provincial Diets until an 1873 law provided for direct elections. The Ausgleich with Hungary in 1867 recognised the Hungarian parliament and nobility as co-equal with the Austrian, with Franz Josef head of both. Within the emerging system, each province maintained its own political structure and indigenous nobility with attendant privileges. Franz Josef was simultaneously emperor of one crown land, king of another and

40 Considering a longer time horizon, one of Kann's theses is that Austria-Hungary became an 'empire' somewhat by a series of accidents, not military or commercial conquest; within, what spread was not homogenous law, but an overarching respect for local custom. R Kann, A History of the Habsburg Empire, 1526-1918 (Berkeley, University of California Press, 1974).

41 This description of the core tenets of Austrian Liberalism was formulated to describe Ukrainian Austrian Liberal Myhhailo Drahomanov. I Rudnytsky, 'Drahomanov as Political Theorist' in P Rudnytsky (ed), Essays in Modern Ukrainian History (Edmonton, Canadian Institute of Ukrainian Studies, 1987) 205.

${ }^{42} \mathrm{~J}$ Bérenger, A History of the Habsburg Empire 1700-1918 (Harlow, Addison Wesley, 1990) 210. 


\section{2}

archduke of yet another, his different titles reflecting the variety of polities he simultaneously headed.

In its peculiar history, as an accidental empire, and in its peculiar means of self-preservation, by striking constitutional compromises (first in the Diploma and then in a series of Ausgleichs) with the polities of its heartland, Austria-Hungary by the early 1900 s was a genre of state distinct from its European contemporaries. The common term 'empire' disguises deep differences: the relationship between ruler, ruled and territory did not follow patterns seen elsewhere in Europe. Austria-Hungary did not seek overseas colonies, was constituted only of geographically contiguous lands and ruled its territories neither by overt military force nor by 'indirect rule'. One reference explains it thus. There was Hungary, and then:

The rest of the empire was a casual agglomeration without even a clear description. Technically it was known as 'the kingdoms and lands represented in the Reichsrat [parliament]' ... These confusions had a simple cause: the empire of Austria with its various fragments was the dynastic possession of the House of Habsburg, not a state with any common consciousness or purpose. ${ }^{43}$

In exchange for confirming the Ausgleich with Hungary, the Liberals won a series of concessions from the Emperor towards securing the rights of individuals, ${ }^{44}$ creating an impartial judiciary and guaranteeing freedom of belief and education. In the non-Hungarian provinces, then, the Austrian Constitution of 1867 gave Austria a Liberal regime. The right to vote was granted to non-noble Austrian men, but under a weighted voting system in which voting males directly elected 72 of 425 members of the Reichsrat. The remaining members were designated to other curia (electoral bodies or voting blocks): great estate owners were allotted a certain number of members of parliament, chambers of commerce others, and rural districts, others. Each provincial elected assembly consisted of similar blocks of seats, to which members were elected by their curia. While the division into curia by forms of property ownership or types of residential locale might have compounded the pluralism of a polyethnic empire, in fact not uncommonly they were associated with ethnicity. For example, in Galicia, large estate owners were almost exclusively 'Polish' (and in Bukovina, Polish or Romanian), meaning that if a family of another ethnicity, say Ukrainian, managed to gain land-owning status, it would adopt Polish language and religion and become Polish. In some cases, crown land Landtag elections may have even served to strengthen

43 'Austria-Hungary' in Encyclopedia Britanica Micropedia (15th edn, London, Encyclopedia Britanica, 2002) 720.

${ }_{44}$ Art 2, Fundamental Law [of Austria] 142, regarding the Crrneral Rights of Citizens. (Article 2 read: 'All citizens are equal before the law.') 
ethnic identities and loyalties, to mobilise voting blocks. The 'compact populations' of the empire may to some extent have been the result of dispersed populatior that compacted themselves: in 1910, one-quarter of the inhabitants of Austria $(6,350,000$ people) had changed their political district. ${ }^{45}$ Records do not show clearly how many stayed in place but changed ethnicity.

Curia is one of many terms for expressing group identities in AustriaHungary, leaving us to grope towards understanding and translation. Take, for example, turn-of-the-century political theorist Mykhailo Drahomanov's explanation that 'the Jews in Ukraine represent [simultaneously] a nation, a religion, and a social class', where 'social class' (the Ukrainian сослоbie (soslovie)), the later historian Rudnytsky tells us, translates literally as 'estate', which is one of the translations offered for curia. ${ }^{46}$ The measures for trying to manage pre-existing systems of privileges and the curia they mark within the legal order of the empire may have informed Ehrlich's understanding of the human associations that, in his theory, form a social order. One can imagine the analogy at work. Nobles enjoyed privileges, special bodies of customary rights recognised by the Ausgleich constitutions and laws. Non-nobles did not enjoy the nobles' advantages and special recognition by the state, but the alternative was not the null set; it was clear that non-nobles too had their discernable bodies of custom and particular sets of rights arising from their legal relations. ${ }^{47}$ Ehrlich sets out to investigate them and proposes their incorporation into the legal order through judicial and administrative decision-making.

The occasional (but not automatic) association of ethnicity with economic identity, such as that which we see in some of the curia, was clear to Ehrlich. In a 1909 work based on research in Roman law, Ehrlich argues that the legal capacity of an individual and his or her position in the economic order are always related. ${ }^{48}$ Likewise, in his early ethnography, a literal investigation into the practices of ethnic groups, he found some of these ethnic-professional affiliations at work in generating bodies of

\footnotetext{
45 R Wischenbart, 'Vienna in 1910: A City Without Viennese' in SE Bonner and FP Wagner eds), Vienna: The World of Yesterday, 1889-1914 (Atlantic Highlands, NJ, Humanities Press International, 1997) 37.

46 M Drahomanov, 'Evreıskı vopros na Ukraine' ('The Jewısh Question in Ukraine') in Sobranie politicheskikh sochinenii 2 (Collection of Political Essays 2) 534, quoted in I Rudnytsky, 'Mykhailo Drahomanov and Ukrainian-Jewish Relations' in P Rudnytsky (ed), Essays in Modern Ukrainian History (Edmonton, Canadian Institute of Ukrainian Studies, 1987) 286. Description of voting rights and the parliamentary system under the 1867 Constitution may be found in J Bérenger, above n 42, 209-89.

${ }_{47}$ Ehrlich points to an example of a non-noble body of rights in the customary-law research of Dzniestrzanksi among the bolken clan of Ukrainians in Galicia. Ehrlich, Fundamental Principles, above n 14, 499.

${ }^{48}$ E Ehrlich, Die Rechtsfähıgkeıt (Legal Capactty) (1909), in the collection of F Kobler, Das Rechts (The Law).
} 
legal relations. For example, in his first work among the rural Ruthenians (Ukrainians) and Romanians of Bukovina, he discovered that there was:

... [a] numerous priesthood, which is made up for the most part of the same families in which this office is usually hereditary, and this priesthood, spread over a wide territory, forms a nation within a nation, which has its own traditions and its own customs. ${ }^{49}$

As he encounters them, Ehrlich treats such professional groups as one of the human associations to be studied for their legal practices; this insight and methodological inclusion marks a significant point of departure from other ethnographers of his day, the Bogošičs and the Bobčsevs. Ehrlich considered both ethnic and professional groups the objects of legal ethnography, treating the two categories as practically analytical equals.

Ethnic groups then were a complicated category, in ethnography and within the law of the empire. For all of its carve-outs for local bodies of tradition, there was a limit to the structural parity given to ethnic groups under the 1867 Constitution. Peoples that had not previously in history had a named, recognised state did not possess any 'state-right' and constituted 'non-native groups' in Austria and Hungary. ${ }^{50}$ Both Ukrainians and Jews, two of the three most numerous populations in Bukovina, were so classified. Just as the curia coalesced into disciplined voting blocks in the Reichsratlike the famous Polenklub of Polish Galician estate owners-political alliances grew up between the 'non-native' groups. After universal suffrage in 1906, incidentally the year that Ehrlich became rector in Chernivtsi, cooperative Jewish-Ukrainian voting pacts yielded electoral successes in the Bukovina Reichsrat elections for both Jews and Ukranians.

A lack of 'state-right' by no means amounted to complete neglect or exclusion by the Austrian state. Language offers many examples. The 1867 Constitution made clear guarantees about the right to receive state services in one's native language, even for those who were linguistic minorities in a subregion. ${ }^{51}$ For example, children were to be educated in publicly funded schools in their mother tongue, if feasible, according to an 1869 federal law. ${ }^{52}$

49 E Ehrlich, 'Professor Ehrlich's Czernowitz Seminar of Living Law', presented by W Page, Proceedings of the Fourteenth Annual Meeting of the Association of American Law Schools (Chicago, Association of American Law Schools, 1914) 58-9 (heremafter: Ehrlıch, 'Seminar').

50 Bérenger, above n 42, 216. A group could thus legally be 'non-natıve' without losing a consensus acknowledgement that its linguistic or historical forebears predated other known groups in a given region. 'Earliest known' could still mean 'non-natıve'.

51 Art 19, Fundamental Law [of Austria] 142. (Article 19 read: 'All natıons [Volksstämme] of the state are equal in their rights, and each nation has the involahle right to preserve and to promote its nationality [Natıonalität] and language. For all languager whose use is customary in a land, the state recognizes equality of rights in schools, government instıtutions, and public life. In those crownlands inhabited by more than one nation. puble mititutions of education shall enable each of the nations to be educated in its languise. withrut being compelled to learn a second language of the land.')

${ }^{52}$ King, above $\mathrm{n} 18,3$. 
Perhaps even more indicative of a bottom-up economy of knowledge in the empire, army officers were to speak the language spoken by a majority of their troops. ${ }^{53}$

New ideas of balance, conscious of ethnicity but not based on traditional privileges, also came into play. For example, different nationalities on local governing boards were balanced to create proportionate representation. ${ }^{54}$ State-based efforts are not the full story, either. People of the empire cultivated other means for regularising friendly contact between ethnicities. Austrian Social Democrat Karl Renner, a native of Bohemia, recalled in his autobiography that his family, like many German peasant families, took part in a tradition of Kinderwechsel, or children's exchange. German children would spend a year living with a Czech family and attending a Czech school, and vice versa. The Czech boys who stayed with his family 'called my parents "Vater" and "Mutter", just as our lads did the Czech parents "Otec" and "Matka". ${ }^{55}$ The children and families who took part, he reminisces, remained life-long friends.

These examples show how Austria-Hungary differed from other models of empire that tried to unite and rule through homogeneity. The important point for our purposes is the space that the empire's official policies allowed for identity to remain unsettled. In its accommodations to a variety of languages and practices in its own heartland, the Habsburg House did not foreclose certain conditions of possibility ${ }^{56}$ for variance among political elites. This is very different from other European states of the time seeking to unite through extension of symbolic systems of the metropolis. In contrast to them and to the totalitarian regimes that later took its place, one would be tempted to call Austria-Hungary a 'fragmentarian' state. The Habsburg dynasty did not insist on a common tongue, try to spread one national origin myth or forge a single national identity. Nor did it use law as a starting point for identity as, say, US governments did. Its concern was with loyalty to the Habsburg House, not to the Austrian Constitution. Emperor Franz Josef permitted the maintenance of separate traditions, different levels of political engagement by curia and a variety of forms of economic engagement, using difference to leverage voting in the parliament. ${ }^{57}$

53 I Deák, Beyond Nationalism: A Social and Political History of the Habsburg Officer Corps, 1848-1918 (New York, Oxford University Press, 1990).

54 For example, national representation on school boards was closely watched (and frequently challenged). See J King, above $n 18$.

55 K Renner, An der Wende Zweier Zeiten (Vienna, Danubia-Verlag, 1946) 46.

56 I am indebted to Alexei Yurchak for directing me to conditions of possibility as a focus of inquiry.

57 This point raises serious problems for Likhovski's application of a Turner frontier hypothesis to understanding Chernivtsi and Ehrlich (Likhovsk1, above n 5). Law and its relation to empire are quite different in his Austrian and US cases. As one example of the differing approaches to governing disparate cultures on the frontier, Austria tried neither to confine the 'other' in reservations nor to contain or exterminate them via cavalry campaigns. 
Nationalism and ethnic identities were increasingly powerful concerns and practices were cultivated to manage inter-ethnic relations. I suggest that ethnography was one way of making sense of this milieu and, in Ehrlich's program, one of many experimental proposals for operationalising toleration that marked this period.

\section{The Supranational Notable and Operationalising Toleration}

At the same time that nationalism was rising, a new figure emerged in late Habsburg Austria defined by expertise rather than origin. A civil service and army were recruited and educated to administer the empire. Cross-cutting associations-the army, the state bureaucracy, commerce-provided home, trajectories, circuits of exchange categorically different from the previous milieus more closely tied to native place or group. Liberal reforms, changing subjects into citizens, reinforced some of the cross-cutting categories, demanding duties to the state and recognising rights, indifferent to origin. As state institutions extended their reach, experience beyond the local began to extend to lower classes. Take, for example, participation in the army. Universal conscription was introduced in 1868. One Ukrainian nationalist newspaper listed the conscription statistics for the province in 1910 as having in significant numbers Ukrainians, Romanians, Jews, Germans, Poles, Hungarians, Czechs and Slovaks. ${ }^{58}$ Conscription imposed duties on all, but also gave openings. As status privileges spread to office-holders, the meaning of ethnicity to others changed as well. ${ }^{59}$

Bérenger tells us that the last decades of the nineteenth century gave rise to a 'human type', the 'Austrian notable' who had received an education in law or a military academy and made his career in the administration

58 The relative numbers are listed for 1900 and 1910 , respectively, as Ukrainians ('Ruthenians'), 297,798 and 305,101; Romanians ('Wallachians'), 229,018 and 273,254; Jews, 96,150 and 102,919; Germans, 63,336 and 65,935; Poles, 26,857 and 36,205; Hungarians ('Madryars' or Magyars), Czechs, Slovaks, and others, 596 and 1005. 'Конскрипція на Буковіні' ['Conscription in Bukovina'], 9 Нюва Буковина [Nova Bukoıına] (Chernivtsı, 2 February 1912) 1.

59 Deák, for example, explains changes related to a specific communicative practice, duelling. Prior to the Liberal reforms, a gentile man might offer an insult to a Jew on the street, knowing that a Jew's status meant that one could ignore a demand for satisfaction in a duel. Army officers not only could demand satisfaction, they were obliged to by the Austrian officer corps' honour code, and other officers were obliged to support each other's right to demand satisfaction. ['It is against the army's notion of honor to refuse chivalrous satisfaction (ritterliche Genugtuung) to a person simply because he belongs to another nation or religious community.'] A Guide for Reserve Officers (1915), commenting on the case of a German nationalist military academy student who lost his rank in the army after refusing satisfaction to a Jewish student who challenged him to a duel, cited in I Deák, Jewısh Soldiers in AustroHungarian Society (New York, Leo Baeck Institute, 1990) 21. As the army incorporated more Jewish officers (by 1897, every fifth reserve officer was a Jew) (Deák, $\imath$ bıd, 17), there was an increasing chance that a Jewish man one met on the street would be a reserve officer and able to demand satisfaction. The incidence of provocative insults to randomly met Jews dropped. 
or the army. 'While acknowledging his ancestry, he felt first and foremost a servant of the state and of the dynasty.' Language and the affiliations it connotes play a role: the Austrian notable was not ethnic German, but 'partially Germanised' ${ }^{60}$ Henri Gobard's model distinguishing different types of languages is useful here. Gobard distinguishes the vernacular, a maternal or territorial language, from the 'vehicular', an urban language of commerce or bureaucratic transmission (as German was in Habsburg Austria). ${ }^{61}$ We might add scholarship to the domains of vehicular language. One striking phenomenon of late Habsburg Austria is the rise of a supranational figure, working for fluency in the vehicular language, at the same time that participation in the everyday affairs of state was reworked to accommodate vernacular languages of the participating nationalities.

Ehrlich certainly fits the description of the Austrian notable. What is peculiar is his self-consciousness. He understands that lawyers, notaries and judges constituted themselves in social formations that could be studied with the same methods that others applied only to 'ethnic groups' and 'natives'. Here we recall the broad scope of his 1903 proposal, where the subjects of his study include judges and document producers with the everyday producers of 'real life' who should be investigated.

\section{From Free School to User Theory of Rights}

\section{Responding to the Multi-national Empire and Constitutional Democracy}

As we saw in Tomaszczuk's vision for the University of Czernowitz, some concepts and organisational methods inspired by the multi-national empire in themselves served as a common purpose and touchstone for Austrian identity. Plurality was taken for granted as the base from which Austrian citizens came, and not necessarily as a centripetal force that threatened the unity of the empire. This is the point of departure for Ehrlich's own ideas on how law works.

Ehrlich took up the perennial question of the age of codification, what to do with 'gaps' in the Code. Ehrlich claimed intellectual lineage with a branch of the 'Free School of Law' following François Gény, who had proposed that gaps should be filled by a 'free decision of the judge', subject to the judge's understanding of social utility, his innate sense of justice and the subject of the dispute (in Gény's words, 'the nature of the thing'). The judge

60 Bérenger, above n 42, 228.

61 Gobard's other types are referential language, entailing cultural reference; and mythic language, caught up in a transcendent spiritual or religious practice (as Latin was in Austrian Catholicism). Henri Gobard cited in G Deleuze and F Guattari, Kafka: Towards a Minor Lıterature, D Polen (tr) (Minneapolis, University of Minnesota Press, 1986 (1975)) 23. 
and his intent replace the legislator and his, as the key figure in juristic analysis and in the practical matter of filling gaps. (Ehrlich took the state's description of separation of powers less literally than Gény, understanding that executive branch administrators could take decisions interpreting regulations that served as the functional equivalent of judicial decisions, but his analytical tack was the same as Gény's.) As Ehrlich notes:

[T] he significance of law in the daily life of a people depends far more on the persons charged with its administration than on the principles according to which it is administered. ${ }^{62}$

Where would one look for sources of law to deal with gaps in the Code? The alternative to the written for Ehrlich is not orality as much as it is custom. Ehrlich had started his career as a classics scholar writing on Roman customary law, and later we see the formative influence of ethnography on his developing theory of what 'custom' is. Looking at the details of daily life, Ehrlich came to the conclusion that by definition humans in society produced social order through regular practices, which in turn gave rise to binding norms. Recall that for Ehrlich, a social association is:

... [a] plurality of human beings who, in their relations with one another, recognize certain rules of conduct as binding, and, generally at least, actually regulate their conduct according to them. ${ }^{63}$

The 'inner order' of associations is determined by what Ehrlich calls 'legal norms', not to be confused with legal propositions. The legal proposition is the 'precise, universally binding formulation of the legal precept in a book of statutes or in a law book'. The 'legal norm' by contrast does not necessarily depend on spoken or written communication for its expression: it is 'the legal command, reduced to practice, as it obtains in a definite association, perhaps of very small size, even without any formulation in words' ${ }^{64}$ Ehrlich worried that legal authorities increasingly slighted customary legal norms in the era of codification. Introductory textbooks assure us that:

... customary law is of equal force with written law. Yet, if one looks at the actual practice rather than the verbal expression, one will soon come to the conclusion that treatises, manuals, essays, and decisions proceed from an assumption-never, of course, openly confessed-that there really is no law except statutory law. ${ }^{65}$

The thrust of Ehrlich's argument here is key: associations of human beings are formed when individuals recognise certain rules of conduct as binding. Ehrlich calls these rules of conduct 'law'. Law is by definition a part of

62 Ehrlich, 'Judicial Freedom', above n 6, 48.

63 Ehrlich, Fundamental Principles, above n 14, 39.

64 Ehrlich, $t b \imath d, 38$.

65 Ehrlich, 'Judicial Freedom', above n 6, 50. 
human associations. Since Ehrlich has already told us that a society is the sum total of associations of human beings, legal pluralism must be an inherent quality of society. Law, then, necessarily takes the form that Bakhtin would call heteroglossia ${ }^{66}$ and what later anthropologists would, in various ways, call legal pluralism. Ehrlich illuminates for us the basic social fact of legal pluralism and further gives us a methodology for tapping into those rich resources as a source of law for state decision-makers. What he neglects to cover is an inevitable product of legal pluralism: conflicts of laws. He does not describe for us what happens when a person, case or collective is simultaneously subject to more than one normative order that conflicts with one another, nor instructs us how a decision-maker should choose between them or reconcile conflicts. This problem is left for the future. It is not a surprise, then, that conflicts-of-laws doctrine is the area taken up as the first major area of US legal reform by Legal Realists (and becomes, perhaps, the source of its greatest cynicism).

Ehrlich was not concerned with homogenising or pluralising. ${ }^{67}$ A note here is in order on space and time, territory and history, in Ehrlich's work. Ehrlich critiques codes not only in their reach across space, but (perhaps more strongly) in their reach across time, not with regard to their heavy hand as much as to their dead hand:

Accordingly, our codes are uniformly adapted to a time much earlier than their own, and all the juristic technique in the world would be unable to extract the actual law of the present from it, for the simple reason that it is not contained therein. But the territory within which our codes are valid is so vast, the legal relations with which they deal are so incomparably richer, more subject to changes than they ever have been ... To attempt to imprison the law of a time or of a people within the sections of a code is about as reasonable as to attempt to confine a stream within a pond. ${ }^{68}$

Weiler argues that the persistent question of Austrian governance was 'from the many, one' or 'out of one, many', and that Ehrlich advocated the latter. ${ }^{69}$ However, as Ehrlich's work proceeded, I think he argued rather for legal decisions that reflect social reality. His argument for an

${ }^{66}$ For a discussion of heteroglossia and dialogism, see $\mathrm{M}$ Bakhtin, 'Discourse in the Novel' in M Holquist (ed), C Emerson and M Holquist (trs), The Dialogic Imagination: Four Essays by M.M. Bakhtin (Austin, TX, University of Texas Press, 1981 (1934-45)) 259-422, particularly at $270-75$.

${ }^{67}$ Likhovski, looking into the generative conditions for anti-formalist movements, tells us that Ehrlich's Chernivtsi was like Pound's Lincoln, Nebraska: a provincial town on the frontier of empire, where different cultures clashed and the legal culture of the centre had only a tenuous hold (Likhovski, above n 5, 622). Ehrlich by contrast conveys the sense that we get of AustriaHungary from other contemporary sources: not an empire using law as a centripetal force, but an agglomeration of rich cultures used by the emperor to forge and manipulate alliances to maintain loyalty to the dynasty (Ehrlich, Fundamental Principles, above n 14, 487-8).

68 Ehrlich, ibtd, 487-8.

69 Weiler, above n 5. 
understanding of law as heteroglossia reflects empirical findings, not a political preference.

It is important to note how this conception of law departs from the Free School. Although Ehrlich does not frame his conception of law as a rejection of the Free School's, we are no longer talking about stuff to fill gaps in the Code. We are talking about multiple legal discourses that carry on constantly and independently of the Code, which Ehrlich proposes judges and decision-makers call on as sources of information about existing law when the decision-maker encounters a gap in law that happens to be written down already. Without fanfare, Ehrlich reframes the Free School discussion of 'gaps' into an account of legal pluralism.

To say that law is more than commands of the state at this point would be redundant. Forestalling some formalist critics, in his inaugural address as rector in 1906, Ehrlich reported conclusions about customary law from his long research into Roman legal history, but as its title shows, he framed it for the contemporary argument. In Die Tatsache des Gewohnheitrechts (The Fact of Customary Law), he concludes that:

... when the classical Roman jurists speak of ius civile they mean Roman customary law; but when they quite generally speak of mores or consuetudo, they do not. ${ }^{70}$

This address seems a carefully calculated attempt to head off critics who would argue that going beyond the state for a definition of law means that just anything could be classified as 'law'. Ehrlich anticipates that argument and inoculates his model against it by demarcating an inside and an outside of Roman customary law. To some extent, though, it cannot be avoided that demarcation is in tension with the holism that underwrites his conception of society and law. The boundary problems that orality, custom and ultimately ethnography raise are still with us.

The radical innovation that Ehrlich proposes to the Free School is that the judge's sense of what to do in an instant case be predominantly informed by careful study of current practice in the domain in controversy. If a case involves suit for damages of spoiled milk from a milk-seller to a buyer, find out what community standards for evaluating milk quality and apportioning risk are, and apply them. Again, it is not that Ehrlich seeks to create many social groups or to streamline them; he assumes that they exist and proposes a means for incorporating their standards into legal decisions. After Nader, who, analysing the development of the common law in the United States, elaborates a 'user theory of law', ${ }^{71}$ I would call Ehrlich's

${ }^{-0}$ Ehrlich, Fundamental Principles, above n 14, 441.

${ }^{-1}$ L Nader, 'A User Theory of Legal Change as Applied to Gender' in The Nebraska Symposium on Motivation: The Law as a Behavioural Instrument 1-33; and L Nader, Life, above n 3, 49. 
approach to addressing gaps a 'user theory of rights'. Like Jhering, he does not believe that rights are metaphysical entities to be found as a part of human make-up, nor are they principles to be deduced and constructed from a code. Unlike Jhering, whose purposive jurisprudence would pose as a primary question for a judge filling a gap, 'What outcome do we want?', Ehrlich would ask, 'What are people doing?'. We understand, then, how the question of methodology becomes central to Ehrlich's program. Ethnography is required for the judge to learn what current practice is. Ehrlich starts his "Seminar in Living Law" to teach law students how to study the details of real life and to enlist them in investigations.

Once discovered by German-reading American legal scholars inspired by the Free School, Ehrlich's work enjoyed rapid dissemination in the United States. The Free Finding of Law and Free Legal Science (1903) and Fundamental Principles of the Sociology of Law (1913) in particular sparked their imagination. News of his efforts to put these insights to work in a systematic ethnographic enterprise to inform legal content, in his "Seminar in Living Law" at the University of Czernowitz, provoked great interest. Ehrlich was invited to address the influential Association of American Law Schools in Chicago in December 1914, but the difficulties of wartime travel precluded his attending. An explanation of his seminar, both its methodology and some preliminary results, were presented in absentia. $^{72}$

\section{In Two Places at Once}

I argue above that, while Ehrlich's methodology, ethnography, was a radical proposal in the Free School's discussion of how judges should make their decisions, it was less striking in the late Habsburg context. A confluence of factors-an emperor tolerant of difference within a frame of dynastic loyalty, Liberal political reforms, rising national consciousness-led to many experiments in operationalising toleration within the structures of governmental organisation and practice across the empire. Pluralism was not only protected; arguably, given the electoral and imperial politics around the new parliamentary democracies in the crown lands, plurality may even have been cultivated.

Ehrlich carved out for himself a position that Nader has described as 'the double marginal', ${ }^{73}$ which became a defining position of twentieth-century ethnographers. Ehrlich developed a methodology based on duration in a time of hit-and-run survey work, conducting his fieldwork right where he

${ }^{72}$ For a summary, see Ehrlich, Seminar, above n 49.

73 L Nader, personal communication, October 2003. 
had spent most of his life, but also insistently plunged into international scholarly discourse. Immersion in the local was as fundamental to his work as his commitment to the cross-cutting associations that defined his professional identity. Though a specialist in the local, he became part of a group of supranational notables, working in the vernacular, but transmitting in the vehicular.

\section{ETHNOGRAPHY (REPRISE): THE NEW ETHNOGRAPHIC METHOD}

What, then, did ethnography come to mean for the Ehrlich of late Hapsburg Bukovina? There are several important ways in which he differs from his contemporaries.

\section{Experience as Method and Science}

Ehrlich argues that social order and social institutions, although not tangible, are susceptible to sense perception. ${ }^{74}$ Every investigator must devise the method that suits his or her own individuality, but 'whatever method or technique it may be, its starting point will always be that which the external world presents to the human mind' ${ }^{75}$ Experience is the basis for Ehrlich's empiricism and a central justification for ethnography as a means of inquiry. As opposed to other sciences based on observation, however, the investigator is not remote from his or her subjects beyond class or professional separations inherent in their milieu. It is the immediacy of perception, the direct experience that makes the work empirical. This kind of ethnography depends on experience as method.

This reliance on experience as a basis for empiricism shows us that although Ehrlich reacted against the 'legal science' practised in the nineteenth century, he does not discard science as discipline and aspiration, but rather thinks through a particular meaning for science. Ehrlich calls for developing both practical and theoretical legal science. Although famous for his promotion of a practical science of law incorporating insights from in situ observation of the 'living law' into judicial decisions, his less famous promotion of a theoretical science of law was no less central to his program for research, teaching and conduct of law. The two are intimately connected for Ehrlich. A theoretical science for Ehrlich is marked by systematicity and deduction based on empirical observation.

Only after a concrete observation is finished does the scientist ask himself whether the principles which he has deduced from the specific observation hold true

-4 Ehrlich, Fundamental Principles, above n 14, 131.

-5 Ibid 472. 
generally; and he can determine this fact only by a series of concrete observations. The same is true for the legal investigator. ${ }^{76}$

Observation, Ehrlich thought, should also be used as part of the method for formulating a problem for research. Montesquieu claimed that he 'laid down principles and saw particular cases yield to them of themselves'. Ehrlich adds:

That is seemingly the genuine scholastic method, beginning with principles and progressing to particular cases by logical ratiocination. But in reality the principles Montesquieu starts with are not conceived a priori. They are all derived from facts he collected, scrutinized, and turned over in his mind during the twenty years he was engaged in his work. ${ }^{77}$

We have discussed how, in Habsburg use, ethnography could be used interchangeably with ethnicity and indicated a descriptive genre. The latter remains the predominant meaning of 'ethnography' in current parlance: one writes an ethnography. As we saw, for other social scientists at the turn of the century, ethnography could also indicate the additional practice of gathering data: one collected ethnographic material. Here, Ehrlich sees the limit that distinguishes his work from his contemporaries. He gathered social facts like Bogošič, Bobčev, Costa and other ethnographers, but, he emphasises, they did not develop their observations into a systematic body of statements, a sociology. Bogošič, for example, 'supplied us with invaluable material' in writing up a codification of Montenegran property law based not merely on the small number of legal propositions, but 'chiefly on the concrete legal relations and legal institutions'. In writing with the object not of a historical understanding but of that which is in existence, today, Bogošič produced a 'recognized masterpiece'. However, nonetheless, 'it would be a vain endeavour to look for general thoughts in his works'. ${ }^{78}$ The only peer whom Ehrlich thinks has taken on the same kind of project, of close ethnographic observation used as the basis for study of patterns and generalisations, was the Austrian-Ukrainian ethnographer Dniestrzanski in his Customary Law and the Social Associations. ${ }^{79}$ In his work, Ehrlich recognised the germs of a number of thoughts like those he was presenting in Fundamental Principles in the Sociology of Law. Data-gathering is not enough. Ethnography also meant a mode of analysing data: one thought through ethnography. Ethnography serves as epistemology.

${ }^{-6}$ Ehrlich, 'Seminar', above n 49, 59.

${ }^{-7}$ Ehrlich, 'Montesquieu', above n 13, 587.

-8 Ehrlich, Fundamental Principles, above n 14, 465-6.

-9 S Dniestrzanski, Das Gewobnheitsrecht und die sozialen Verbände (Customary Law and - he Social Associations) (Czernowitz, 1905), cited in Ehrlich, Fundamental Principles, above n 14,465 and 499. 
The Humanities and the Place of the Translator

Ethnography as epistemology requires a certain sort of food for thought. Vienna's other new social sciences, like psychology, agreed that what was understood as 'artistic sensibility' is part of good social science.$^{80}$ Ehrlich firmly located his ethnographic work at the intersection of science and art.

Every true work of science is a work of art, and the man who is not an artist is a poor man of science. Production of a work of science requires the same qualifications as production of a work of art. ${ }^{81}$

He understood this to have methodological implications. As artists:

... every independent investigator must create his own method, just as every creative artist must create his own technique ... For the mind which thinks and works independently will ever be seeking new methods and new techniques which correspond to his individuality. ${ }^{82}$

While Ehrlich here acknowledges the role of creativity in scientific inquiry, that is not to confuse scholarly work with creation or individuality with authorship. Rather, implicit throughout Ehrlich's project is a central purpose: ethnography itself was to be an act of translation. He emerged from Austrian pluralism with a goal not of homogeneity, but of communication. In Ehrlich's program, the natives' own legal documents, practices, customs would be translated from the vernacular into the vehicular language of bureaucratic administration of justice.

Ethnography is translation in another respect. The ethnographer is not correctly understood as the author of ethnography; rather it is the subjects, the group of humans under study, who have produced the content. The ethnographer is transcriber, except that in most cases the target reader is one who does not understand the vocabulary of practice being presented. If the ethnographer has made the switch to a methodology of the humanities, adopting the natives' own terms and ideas for understanding practice from within, the analysis he or she produces is not mere reproduction, still unintelligible to the alien reader. Instead, the ethnographer is translator of that which a collective has authored, as Ehrlich has taught us, as a body of custom. Here is where we see the old story of tool-use retold: the tool was fashioned and eventually the tool refashioned the tool-bearers. In Ehrlich's case, ethnography transforms his work from legal theory to social science, but instead of a grand science of eternal truths, one of emergent tales of

80 See also Malinowski, Argonauts of the Western Pactic (Prospect Heights, IL, Waveland Press, 1984 (1922)) 18.

${ }^{81}$ Ehrlich, Fundamental Principles, above n 14, 472.

82 Ibid. 
the particular. Ethnography can transform the ethnographer from master scientist into translator of the vernacular.

\section{EPILOGUE AND CONCLUSION}

\section{Epilogue}

There is a tension to this day in ethnography between an Enlightenment commitment to human universals and a Romantic commitment to particulars. Ehrlich's program for a sociological jurisprudence, like many Austrian experiments in governance, sought to integrate the particular into the whole. However, Ehrlich's laboratory of a legal science and the pluralistic empire it served succumb to the former.

On 22 October 1918, a Romanian propaganda organ Glasul Bucovinei (Bukovina's Voice) began to appear in Chernivtsi. Its editorial board attacked Bukovina's 'Austrian' pluralist tradition and urged Romanian-speakers to unite. On 17 October 1918, a Romanian National Council had formed in Vienna in response to the emperor's manifesto calling for the federalisation of Austria based on nationalities. In his last imperial audience, the president of the council informed Franz Josef that the Romanians would vote against a reformed monarchy, the equivalent to a declaration of ethnic Romanian secession. On 27 October 1918, a Constituent Assembly of the Romanians of Bukovina met in Chernivtsi and voted for the union of Bukovina with other 'Romanian lands'. These moves carried ominous overtones: already in prewar Romania, a struggle for national self-definition against the pluralism and toleration of Austria across the border had resulted in part in an understanding that 'to be Romanian became synonymous with being an anti-Semite'. ${ }^{83}$ At a 'General Congress' in Chernivtsi boycotted by Ukrainians and Jews, Romanian, German and Polish delegates voted unanimously for the union of Bukovina with Romania. The ambitions of France at the Paris negotiations at the end of the War, eager to reward Romania as a perceived ally and to establish it as a buffer state, aligned with those of Romanian chauvinists. Bukovina was incorporated into Romania in January $1919 .{ }^{84}$

That same month, a new Romanian administrator, Ion Nistor (who had been one of the underground editors of Glasul Bucovinei), took the rectorship of the University of Czernowitz (the post Ehrlich had held at the beginning of his reform program in 1906). Nistor declared in his first speech as rector that he sought to purge the province and the university of a despised

83 Livezeanu, above $\mathrm{n} 22,12$.

84 This information on the Romanian takeover of Bukovina summarised from Livezeanu, above $n$ 22, 57-9. 
species, homo bukovinensis, the name he gave to a creature that tolerated the mishmash of communities and thrived under pluralism. Ehrlich, like all but three faculty members of the two secular departments of the university, was an Austrian who did not speak Romanian. The student body was also mixed. The last figures from before the First World War, the 1913-14 school year, give a total of 1,198 students at the university, including: 401 Jews, 310 Romanians, 303 Ukrainians, 86 Polish and 57 Germans. ${ }^{85}$ Nistor 'invited' non-Romanians on the faculty to use Bukovina's new official language, 'failing which they would have to leave'. Only four Austrian professors consented to these conditions and remained. Decree 4091 of 23 September 1919 formally transformed the Austrian University of Czernowitz into the Romanian University of Cernăuți. ${ }^{86}$

Withdrawing to Vienna offered scant respite. As Wittgenstein wrote to Bertrand Russell in 1918 upon returning home to Vienna from the Italian prisoner-of-war camp in which he spent the last nine months of the war, 'The city is starving'. ${ }^{87}$ The conditions of Ehrlich's last years are murky. It is said Ehrlich died on 22 May 1922 in Vienna, although Pound thought it was 1 April. ${ }^{88}$

\section{CONCLUSION}

What are ethnography and a human science good for? In the spirit of modernism, one would be tempted to issue a ringing conclusion. One could issue a call to the new science, an empirical science using experience as the method of data collection and basis for analysis. Ethnography could yield hypotheses tested by local observation and challenge hypotheses alien to experience. Ethnography depends on the notion that understanding of human experience can transcend context. Ehrlich emphasised that we could learn about the plurality in which we live, but implicitly he also argued that it should inform a more comprehensive science of law that could claim broader insights about human ordering. This commitment affirms that we can learn from each other about ourselves. With ethnography as a tool, one is uniquely equipped to advocate for the species. Go forth, make science!

However ... it would also be true to Ehrlich to give a more modest answer. This is what I mean by modesty. Ehrlich's legal science differs from

\footnotetext{
${ }^{85}$ F Riedl, 'Die Unıversıtät Czernowitz, 1875-1920: Ein Blıck auf ıhr Wesen und Ihre Entwicklung Bezıehungen zu Ost- und Mitteldeutschland' 2 Mitteldeutsche Vorträge (1971) 19, cited in Livezeanu, above n 22, 231.

86 Livezeanu, above n 22, 231.

$8^{-}$L Wittgenstem, GH von Wright (ed), Letters to Russell, Kevnes, and Moore (Oxford, Basil Blackwell, 1974).

88 R Pound, obituary note on Eugen Ehrlich as preface to Ehrlich: 'The Sociology of Law' (December 1922) 36 Harvard Law Review 129, 129.
} 
his contemporaries in social science and even from many of his fellow jurists' legal theory. For him, law is simply a way of discussing that which arises from normal human conduct, another way of describing society as current practice. The late Habsburg political structure left room for local traditions and political orders, and does not convey a sense of lack regarding those spaces where the law of empire did not intrude. This seems to be Ehrlich's sense as well. Let the worker bees buzz and bumble between their sections of the hive, let them do their work of building, repairing, filling in, carrying away. You could speak of 'gaps' and, while not incorrect, it would seem a strange characterisation of a honeycomb that is defined as much by its empty spaces as by its connectors. Such, for Ehrlich, is an understanding of society and law.

Ehrlich's program seems less totalising and more contemporary and useful to us. Ehrlich's work involved going out and talking to individualspeasants, priests, notaries, traders, businessmen-understanding in each modest strand of legal relations that 'society' is nothing more grand, nor less, than that. Modest, yes, but still ambitious, clear, close to the ground, empirical. Ehrlich's work takes his fellow citizens seriously enough to pay attention to their details and, as a social scientist recognising their practice as already law, his legal reform program gives them authority to create law.

Ehrlich does not use ethnography to create a new set of eternal truths, a new mythic language that one must master in order to establish authority in law. He is not blind to power relations based on knowledge, but he offers an alternative to acquiescence or rebellion. Instead, Ehrlich takes on the work of translating the vernacular into the vehicular language of state administration. His program could be read as a blueprint for governing in the vernacular. The ethnographer, as translator, is a key link, but does not claim to produce law or to know the right answers. His proposals rest on observations of the law that others are already practising.

This is a different kind of authoritative discourse, different from existing science and law. Ethnography in Ehrlich's hands does not furnish bricks to build a grand edifice, but the components for a simple mirror. The technology does not fix the image in place; in fact, it is chosen because it reflects the contemporary, the emergent. The ethnographer holds it up so that we see the scientific claim, the legal authority, is the prosaic, changing image of ourselves and our fellow persons in the mirror. 